
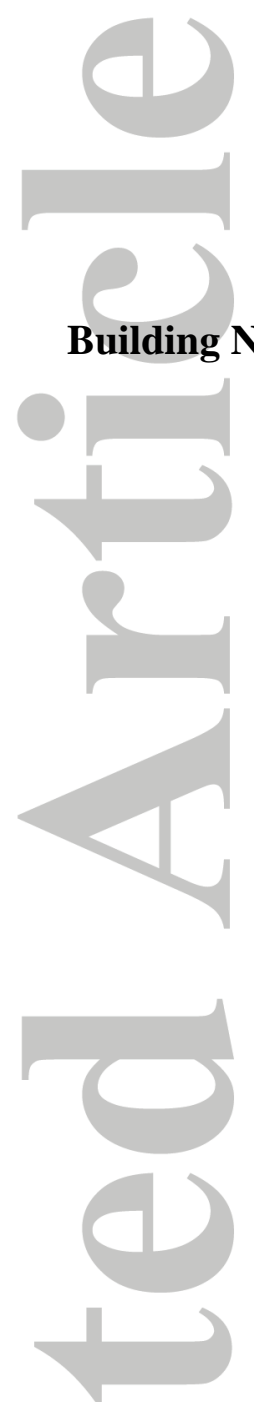

\author{
Neil Gunningham (1) \\ Professor, School of Regulation and Global Governance (RegNet) \\ College of Asia and the Pacific
}

The Australian National University

Acton

ACT 0200

Australia

This article has been accepted for publication and undergone full peer review but has not been through the copyediting, typesetting, pagination and proofreading process which may lead to differences between this version and the Version of Record. Please cite this article as an 'Accepted Article', doi: 10.1111/lapo.12083 


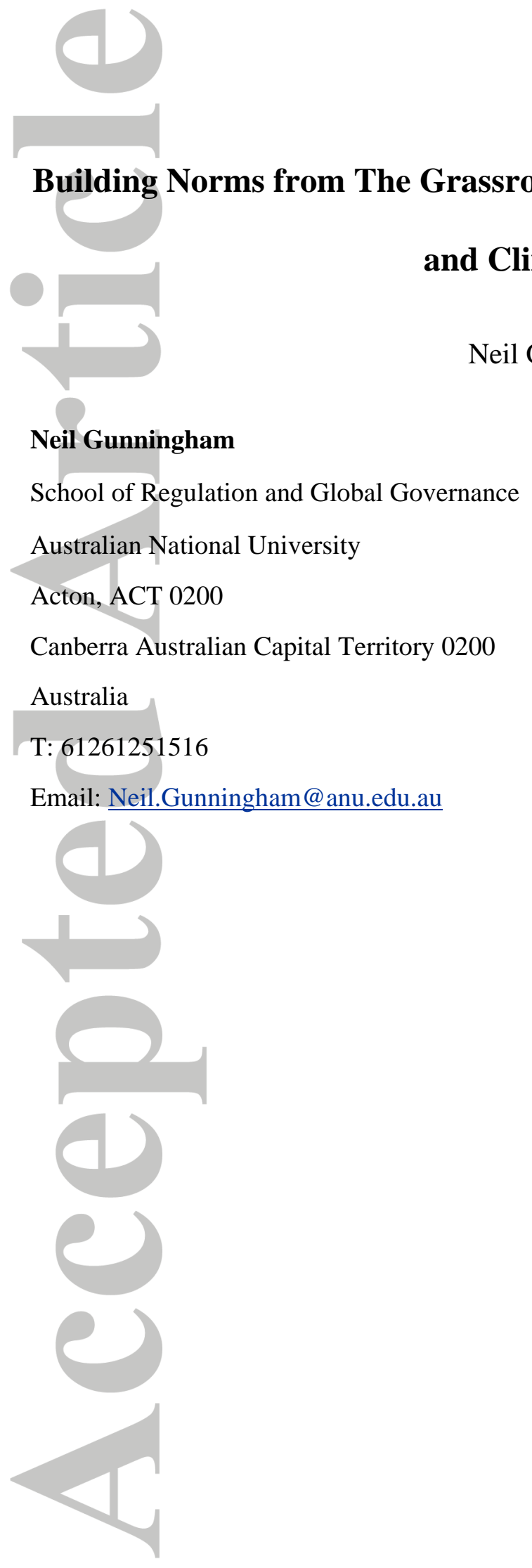




\title{
Building Norms from The Grassroots Up: Divestment, Expressive Politics, and
}

\section{Climate Change}

\author{
Neil Gunningham
}

The fossil fuel divestment movement is at the forefront of civil society initiatives to raise public consciousness about the need for a 'fossil free' future. Through the lens of the social movement literature, this article shows how the movement has harnessed grassroots activists, engaged in innovative and sometimes disruptive forms of protest and used cognitive framing and symbolic politics to gain media interest and persuade the public of the importance and legitimacy of its claims and to promote a new social norm. The relative instrumental, structural and discursive power of the protagonists is also examined, showing how, notwithstanding the industry's deeply embedded structural and instrumental power, the movement has managed to shift the contest onto a terrain where it holds a comparative advantage. Finally, the movement's role in non-state climate governance is considered, taking account of its interactions with and impact on a range of other climate actors and concluding that climate governance is not only an instrumental or pragmatic process of mandating changes in behavior, but an expressive and symbolic one of nurturing a new norm and institutionalizing a new set of moral principles.

I am grateful for the excellent research assistance of Lucy Caldwell and David Rowe and for the comments of Julie Ayling, Christian Downie, Darren Sinclair and two anonymous reviewers. Responsibility for any errors is, of course, my own. 


\section{I: Introduction ${ }^{1}$}

In 2008, environmental writer and activist Bill McKibben and six of his students established the climate activist group 350.org. Each took responsibility for coordinating mass public actions on one of the seven continents. 350 parts per million is regarded by climate scientists as the safe upper limit for atmospheric carbon dioxide levels, beyond which we risk "dangerous climate change" (Hansen et al 2008).

Until 2012, the group participated in various campaigns with some success, but its ambition, reach, and direction changed dramatically following the publication of McKibben’s Rolling Stone article, “Global Warming's Terrifying New Math” (McKibben 2012). This set out the case for keeping most fossil fuel reserves in the ground to avoid catastrophic warming and led directly to what became 350.org's divestment campaign. Building on existing campus activism, 350.org catalyzed multiple campus-based minicampaigns aimed at pressuring individual universities to divest of their fossil fuel assets. The campaign subsequently expanded globally, moving beyond universities to other institutional investors vulnerable to moral appeals to divest. As other activist groups also mobilized under the banner of going "Fossil Free," a new social movement was born.

The movement rapidly evolved into a transnational activist network with multiple nodes working in concert across national borders (Keck and Sikkink 1999). By December 2016, the movement had been instrumental in persuading 688 institutions (including major banks, insurers, and investment funds) and 58,399 individuals across 76 countries to commit to divesting from fossil fuel companies based on climate change concerns. The value of assets represented by these institutions and individuals is conservatively estimated at US \$5 trillion, up from \$3.4 trillion the previous year (Arabella Advisors 2016). As such, and as 
further described in the Review Essay (Gunningham 2017, this Issue, above), the movement's growth has been dramatic, and it is becoming an increasingly significant climate change actor on the global stage. International organizations, policy think tanks, major foundations, and the media have recognized the growth and influence of the divestment campaign to be remarkable, variously describing it as "the most important action that ever happened on climate change" (Joachim in Divest-Invest Philanthropy 2015), as "arguably the most effective and well organised enemy of fossil fuel in the world" (Stevens 2016), and as "the fastest growing [such] movement in history" (Vaughn 2014).

How did a group that in 2008 was little more than a handful of students and a faculty member, come to have such an impact on climate change discourse in so short a time, and how did it succeed in putting such a powerful, well-resourced, and well-established adversary as the fossil fuel industry on the back foot?

Through the lenses of the social movement literature and, to a lesser extent, the literature on non-state governance (on the latter, see further Review Essay, this Issue), this article examines how the political and normative contest between the divestment movement and the fossil fuel industry is playing out and the implications for theory and practice. In doing so, it explores ground that has, at most, been only lightly trodden in previous analyses. For example, focusing on the divestment movement as a moral entrepreneur and on norm development may compensate for the disproportionate emphasis on rulemaking, and especially certification and standard setting, within the existing literature on non-state environmental governance. It therefore not only gives due weight to the importance of power but to different types of power and how a weak actor may shift the contest onto a terrain in which they hold a comparative advantage. Again, little has been written about 
"deep green" social movements, which eschew co-operation in favour of confrontation and disruption (Bulkeley et al. 2014), about their role as discursive entrepreneurs harnessing their symbolic capital, or about institutional investors as agents engaged in climate governance (Macleod 2011). Finally, in contrast to much of the social movement literature, which focuses predominantly on conflicts between such movements and the state, this study explores a contest between an incumbent industry and the movement in which the state has often been little more than a bystander.

In terms of methodology, and recognizing that activist networks are best studied through their campaigns and their impact, a case study approach was adopted, focusing on the movement's progress for the first five years of its existence (2012-2016). Consistent with this focus, the principal methodology was qualitative field-based research, which was undertaken principally in Australia and the USA, two of the three countries in which the movement has been most active. Specifically, in accordance with generally accepted principles (Minichiello and Hays 1995), thirty-two semistructured interviews were conducted in 2015 and 2016 with a sample of stakeholders including activists, campaign managers and influential figures within the movement, investment fund managers (particularly those vulnerable to public pressure), banks, and industry consultants.

The semistructured interviews took approximately 30-45 minutes and were based on a series of questions and prompts intended to explore in detail the central policy and governance issues identified in the body of this article. The substantial majority of interviews were conducted in person; a minority were conducted by phone where logistics made face-to-face contact impracticable. There was a high response rate (almost $80 \%$ ), likely because participants were guaranteed anonymity and because many of them 
welcomed an opportunity to state their views on an issue of considerable importance to them. The notable exception was the fossil fuel industry, where requests for interviews were declined. Participant observation of divestment campaign events such as national days of action, strategy meetings, phone banking, and local activist events complemented the interview data. Efforts were made to compensate for the absence of interviews with fossil fuel companies by examining publicly available statements from members and representatives of the industry, which are numerous.

The above data were supplemented by available documentation and data to corroborate, illustrate, and/or challenge participants' statements in interviews and to verify factual details and statements of participants' intended aims and aspirations. For example, documentation from relevant NGO websites explaining their goals and strategies and corporate press releases criticizing the divestment movement were found to be useful complements to the interview data. In addition, using the Factiva news retrieval database, article searches were performed on newspaper coverage of the divestment movement in the three countries examined (covering the period of 2012-2016). Finally, the social movement and nonstate climate change governance literatures were examined. The latter is more fully explored in the Review Essay above, which can usefully be read in conjunction with this article.

The focus of this article is the "activist" arm of the divestment movement, or what some refer to as "the broader people's climate movement," and on the various divestment campaigns. As such, the article touches only briefly on the role of the financial arm of the movement, whose emphasis is more pragmatic and instrumental and which is concerned 
with helping create the conditions in which carbon taxes and other financial reforms can be harnessed to end short-termism in financial markets and with encouraging, rewarding, and facilitating investors to re-invest in energy efficiency, renewable energy, and other sustainability initiatives (Divest-Invest Philanthropy 2015).

Unless otherwise stated, the "divestment movement" is used to refer to the cluster of loosely allied groups of activists, including the student organizations, community-based groups, and coalitions of like-minded bodies and institutions that are orchestrated by 350.org and/or its affiliates. These include, but are not limited to: the Responsible Endowments Coalition (REC), Energy Action Coalition (EAC), As You Sow, Coal Swarm, and the Sierra Student Coalition in the United States; and Solar Citizens, Market Forces, Get-Up, Lock The Gate, the Australian Youth Climate Coalition, and the Sunrise Project in Australia. Broader alliances have also been developed with various community, religious, and special interest groups. For the purposes of this article, norms are shared understandings and values that shape preferences and identities and legitimize behavior. Where activists are quoted below, "A" (as in "350A") denotes Australian respondents, while "USA" denotes their American counterparts.

The structure of the article is as follows. Part 2 explores the movement's targets, the strategies it has employed to achieve its objectives, and how and why an industry countermovement has developed new strategies to defend the energy status quo. Part 3 discusses the rise of a fossil fuel industry counter-movement, the tactics it uses, the impact it is having, and the divestment movement's response. Part 4 examines the relative instrumental, structural, and discursive power of the protagonists, showing how the movement has engaged its adversary in the "currency" in which it is strongest. It also considers, albeit 
briefly, the movement's role in nonstate climate governance, taking account of its interactions with and impact on a range of other climate actors. Part 5 concludes the article.

\section{II: Targets, Tactics, and Strategies}

The divestment movement has two principal targets: the fossil fuel extraction industry, whose behavior it aims to stigmatize, and the public, whose norms and perceptions of a "social problem" it seeks to shape. It also seeks, as the vehicle through which to impact its principal targets, to pressure an intermediary group — institutional investors - to divest their stocks from fossil fuel extraction companies and to reinvest in clean energy alternatives (see further Review Essay, 2017, this Issue). But why embrace the tactic of divestment? Why opt for conflict rather than cooperation or engagement, and why target the private sector rather than government? ${ }^{2}$

Focusing on divestment has the considerable attraction of relying on an existing "repertoire of actions" (Yazuii and Doh 2013, 758) that has been demonstrably successful in a related context. Doing so involves far less of a leap into the unknown than developing and rolling out a new strategy would, which in part explains why so many organizations choose to model themselves on others. As the movement makes clear, the model it chose to follow was that of the antiapartheid divestment movement of the 1980s, a campus-based initiative that eventually prompted over 150 universities in the United States and a significant number in other developed countries to terminate their investments in companies associated with the apartheid regime in South Africa. Moreover, this campaign, like others before it, proved "successful in lobbying for restrictive legislation" (Seidman 2015; Carrington 2013) and 
"helped reveal the immorality of apartheid, galvanizing a movement of concerned citizens around the world" (350.org, 2014, 5).

In both Australia and the USA, the divestment movement rejects accommodative approaches as being wholly unsuited to achieving its far-reaching goals. After all, it is not seeking to improve the energy and climate change status quo but to fundamentally undermine and reconfigure it. Accordingly, it aims not to dialogue with the fossil fuel industry but to destroy it, starting with the top 200 carbon emitters, "not because they fail to conform to dominant institutional standards but precisely because they do" (Yazuii and Doh $2013,763)^{3}$. Given the irreconcilable differences between the interests of the industry and the movement, contrainstitutional activities such as demonstrations and other contentious actions are preferred to compromise.

All political players have a choice between private and public politics (Barron 2001). The divestment movement's embrace of the latter reflects disillusionment with the capacity and willingness of states to engage seriously with major environmental problems. As one activist put it, "Government is dead and we are struggling to work out how to deal with that" (350A). Mindful of the past failure of environmental NGOs to enlist the state in their cause, 350.org has abandoned ineffective domestic lobbying in favor of alternative strategies aimed at an offending industry sector. Ultimately, their aim is still to influence governments, since only states and international organizations can mandate climate change mitigation on national and global scales. However, the favored strategy is to raise public consciousness in the belief that governments will only be willing to take decisive action in response to a groundswell of popular support. 
Light green, "moderate" environmental groups such as the National Resources Defense Council (NRDC) and the Australian Conservation Council have arrived at a similar conclusion through bitter experience. Notwithstanding their preference for technical analysis and policy advocacy, they now recognize that neither of these approaches will be sufficient to bring about transformational change without an underpinning of grassroots support (Beinecke 2015, 714). As one senior NRDC representative put it, "Environmentalists can't diffuse this crisis alone. People from all walks of life must raise their voices" (Beinecke 2015, 724). It was this recognition that, in large part, prompted McKibben and others to launch the divestment movement in coordination with their more moderate allies and with other activist initiatives such as the antifracking and Keystone Pipeline campaigns.

Put differently, divestment is best seen not as a "stand-alone" initiative but as part of a broader strategy that has evolved as environmental organizations - both light and dark green-have learned from experience the limitations of government-focused action and the importance of mobilizing "a fully deployed and engaged grassroots . . . demanding climate action" (Beinecke 2015, 715) ${ }^{4}$. Such coordination is less evident in Australia, perhaps because the movement could largely adopt the strategy and tactics of its American sister organizations without needing to engage with more moderate environmental organizations. According to one campaigner, "Our coordination isn't as good [as the USA]. We have followed the US but we are some years behind" (350A). Even so, the "Stop Adani" campaign of 2017, which opposed the building of a mega-coal mine by the Indian conglomerate in the Galilee Basin, is supported by thirteen environmental groups, including the Australian Conservation Foundation and other "mainstream" NGOs (Stop Adani 2017). 
While the movement is closely identified with what, to date, has been its core strategy of divestment, it is unlikely in the future to confine its activities to that strategy. On the contrary, it recognizes the need to stay at least one step ahead of the fossil fuel countermovement and to move forward on a broad front. As one Australian campaign manager put it, "Every good campaign needs a repertoire of tactics. You can only flog one tactic for so long" (350A). At some time, divestment will cease to be perceived to be either new or news, but by that time the movement anticipates having developed a plethora of other strategies to advance its fundamental objective: promoting a new social norm and, through this, dramatically curtailing the use of fossil fuels.

Accordingly, divestment is simply one approach among many, capable of mobilizing various constituencies (students, religious groups, philanthropic foundations). Once complementary strategies (non-violent direct action, mass protests, on-line petitions, consumer boycotts, strikes) seem more likely to gain traction, they will be embraced and divestment relegated to the periphery. Depending upon the context, any of the above strategies may prove capable of raising awareness of a particular cause, emphasizing the cause's moral "rightness" and the immorality of its opponents, whom it seeks to shame. Such strategies moreover, can often be used not only in isolation but also in combination in order to variously raise awareness (through marches, rallies, and other forms of protest) and to pressure their targets directly (through boycotts, non-violent direct action, and efforts to ban the targeted activity). ${ }^{5}$

The contemporary movement, like its predecessors, is essentially concerned with moral imperatives: with threatening the reputation and social license to operate of its adversaries rather than their share prices (Gunningham 2017, this Issue). As one leading 
activist points out, "no states banned the use of tobacco, but we did change the conversation in profound ways. And eventually, once public opinion leads, then states follow" (McKibben and Parentii 2013, emphasis added). Indeed, following this insight, a fundamental aim of the divestment movement is to convince target audiences to embrace a new norm: the desirability of going "fossil free," implying the need to transition to a zero-carbon economy. To do so, the movement must act as a moral entrepreneur (Gusfield 1963), capturing the attention of the public and highlighting the issue of climate change in the public consciousness.

Recognizing the central importance of the news media in disseminating information to and engaging mass publics, the movement favors tactics that create an ongoing sense of drama, such that the media's (and thereby the public's) attention to the issue does not fade. Under the go "fossil-free" campaign, it not only publicizes and celebrates ongoing divestments but also, recognizing the importance of innovation, engages in a range of “creative actions" likely to gain media attention. These include "photos, stunts, and petition hand-ins . . . colourful orange flash-mobs, mass occupations and student sit-ins" (Go Fossil Free 2015), to which should be added various forms of civil disobedience, disruption, and direct action. These activities, particularly those of a confrontational nature, not infrequently generate a backlash from politicians, industry groups, and conservative think tanks and media that dispute the need for climate change mitigation. This in turn often serves to increase publicity, drawing still more attention to the movement.

It is through such activities and through multiple emotionally charged appeals that the movement aspires to have a moral and symbolic impact. This impact should not be underestimated (Edelman 1971). As Eaton points out, the "symbolic, metaphoric and 
imaginative mode of being is the modus operandi of humans. A symbolic consciousness is the way humans process and navigate the world" (Eaton 2011, 14). In the case of the slave trade, for example, although the abolition campaign did not in its first iteration succeed in prohibiting slavery, it did have a considerable impact on the public discourse, such that slavery became widely perceived as immoral (d'Anjou 1996, 45) ${ }^{6}$.

The enterprise of launching a "moral crusade" (Gusfield 1963) and of promoting a new norm also requires an "organizational platform" from and through which to persuade target audiences of its desirability (Finnemore and Sikkink 1998). This platform might be provided by an existing entity, such as an international organization, or by creating a new one designed specifically for that purpose. Self-evidently, the divestment movement has opted for the latter approach.

The movement's structure and modus operandi enable it to provide such a platform even in the absence of significant material resources. This is because its "resource mobilization" (Zald and McCarthy 1987) needs are human rather than financial. For example, engaging in civil disobedience or direct action requires little training, capital, or networks (Yazuii and Doh 2013). These characteristics have enabled the movement to expand rapidly, harnessing a multitude of self-organizing, voluntary groups ${ }^{7}$ who run grassroots, locally-driven campaigns built around "people power." These campaigns can be readily mobilized by at-scale digital communications and by the use of particular online platforms such as Facebook. Divestment is also attractive as a protest technique because it can be readily replicated across universities and other institution, as well as across countries, and because it can be targeted at institutional investors wherever they may be. Indeed, some commentators have referred to this approach as involving a deliberate form of 
disorganization that is strategic in its avoidance of hierarchical power relations and its emphasis on autonomy (Anderson and Herr 2007).

The capacity to mobilize effectively is also a matter of political opportunities, defined as "options for collective action, with chances and risks attached to them, which depend on factors outside the mobilizing group" (Koopmans 2004, 65). For example, following McAdam (1996), the relative openness of the institutionalized political system in developed democracies and its limited propensity for repression have enabled social movements to flourish within them. While there are well-documented limitations to the "political opportunity" approach to contentious politics (McAdam et al, 2001), some of its insights remain helpful—particularly its recognition that opportunities must be perceived in order to be taken advantage of (Gamson and Meyer 1996). As discussed above, McKibben and his original student cohort were particularly astute in recognizing the opportunities that divestment provided as a vehicle for political engagement and the potential for such a bottom-up and decentralized approach to be rolled out across multiple different countries, while recognizing that this approach would be challenged in authoritarian countries.

As a recently established outsider, the movement has had little choice but to employ the tactics of the weak, seeking to mobilize citizens outside the policymaking community in a bid to gain leverage over those on the inside (Kollman 1998; McAdam 1983). Those on the inside, moreover, are not merely individual companies, some of whom might be played off against others, but an entire industry with deeply embedded structural and instrumental power, the latter including its overwhelming financial and political resources orchestrated through well-oiled and richly resourced industry associations. 
For these reasons, like various social movements before it, the divestment movement also uses tactics that are "subversive and disruptive in nature-to challenge authority and broadcast grievances from the margins of society" (King 2011, 491). Boycotts, protests, and divestment are popular because such "extrainstitutional tactics," as King calls them, "have the potential to disrupt the resources and routines of their target organizations. Disruption in turn pressures a target to pay attention to activists' claims and potentially forces targets to concede to their demands" (Ibid. 491). Indeed, to challenge existing "logics of appropriateness" (March and Olsen 2004), activists may need to be explicitly "inappropriate" (Finnemore and Sikkink 1998). Just as suffragettes chained themselves to fences and broke the windows of government institutions, so divestment activists "lock on" to gates and engage in other acts of civil disobedience. Such deliberately inappropriate acts "can be powerful tools for norm entrepreneurs seeking to send a message and frame an issue" (ibid. 897). They have the further advantage of not only engaging with the public but also of threatening the social license to operate of their reputation-sensitive opponents. In this contest, even the movement's weakness may be turned to its advantage by allowing it to present itself as a heroic underdog, while its lack of material interest enables it to take the high moral ground.

It is also the case that, as institutional theory emphasizes, all actors are embedded in social institutions from which they derive their legitimacy. As Julia Black points out (Black 2008), amongst the relevant strands of institutionalism are the following: a behavioural or regulative dimension, which provides norms of action that are externally enforced ("Divest because it's the right thing to do, and we'll shame you if you don't'); a cognitive dimension 
involving beliefs and understandings of cause and effect ("If you don't divest, you'll end up with stranded assets when the carbon bubble bursts"); and a normative dimension that provides social mores of appropriateness and legitimacy ("Divesting is proper and desirable and will result in societal approval").

This connects to the final, and crucial, set of factors that explain the remarkable trajectory of the divestment movement: its capacity for "naming, shaming, and framing." There is considerable evidence that identifying a tangible enemy is crucial to success, and McKibben recognized at the outset that the climate debate "lacked a clearly defined adversary." The movement's "go fossil free" campaign "named" such an adversary in the form of the fossil fuel industry in general and the top 200 carbon polluters in particular: "We didn't have a clear cut bad guy. The campaign created one. It created a pariah" (350.org campaign manager UK).

The movement has also coupled the designated villain's behavior with an "injustice frame" that identifies the victims of climate change (our children's children, those in developing countries, future climate refugees) and how that injustice might be remedied. Other perceived advantages of the movement's approach include the fact that the problem can be presented, with compelling scientific support, as a global crisis and that the ultimate target is an entire business sector (while making individual organizations the subject of specific campaigns). Mckibben's labeling of the fossil fuel industry as "Public Enemy Number One to the survival of our planetary civilization" (McKibben and Parenti 2013) neatly encapsulates these frames. 
Having identified the enemy, the movement seeks to "shame and blame" them, by attacking their reputation and challenging their viability in a climate-constrained world. As we have seen, this movement does this primarily through its engagement with institutional investors, particularly those likely to be amenable to moral arguments. There is no doubt, however, that the real target is the fossil fuel industry itself, which it has characterized as immoral, unscrupulous, and intransigent. As McKibben puts it, "Our job is to help people come to understand that these are now rogue industries-that, quite literally, if their business plans are followed, the planet tanks" (Jarvis 2013).

As/such, its central role was to stigmatize targeted fossil fuel businesses, to label their activities as immoral and, through this, to nurture the development of a new social norm (the virtue of going "fossil free"). As a number of sociologists have pointed out, such "shaming movements" have become increasingly common over the last few decades as recognition of the importance to corporations of their "reputation capital" and social license to operate has grown. Shame, such studies reveal, "can be deployed to promote new norms and values, rather than simply to reinforce old ones: by forcing audiences to confront moral contradictions, activists can mobilize support for social change" (Seidman 2016, 351-352). Shaming movements have been employed variously against apartheid, to protect the rights of indigenous populations, and to mobilize global publics in the case of climate change. The US temperance movement and the UK slave trade abolitionist movement are much earlier examples (Seidman 2016).

The final and crucial component in the armory of a moral entrepreneur is cognitive framing. Publicity is the oxygen that activist networks need to flourish. Notwithstanding the increasing role of social media, it remains the case that, starved of media attention, activist 
networks struggle to disseminate their messages to mass audiences. Gaining that attention requires framing the issues in such a way as to garner media interest. This involves "conscious strategic efforts ... to fashion shared understandings of the world ... and of themselves that legitimate and motivate collective action" (McAdam et al. 1996, 6) and “call[ing] attention to . . . or even 'creat[ing]' issues by using language that names, interprets, and dramatizes them" (Finnemore and Sikkink 1998). Framing also has a related function, given that how something is presented to the audience shapes the choices people make about how to process that information. As such, frames may influence an audience's perception of the news not only by telling the audience what to think about but also how to think about it.

So it is with the divestment movement, which seeks to frame the issue of climate change in such a way as to justify a particular course of action. The movement itself is not reticent about what such a framing should involve. It identifies its three core frames as (1) the fossil fuel industry is incompatible with a just and sustainable future ("If it is wrong to wreck the planet, then it is wrong to profit from that wreckage"), (2) social, racial, \& economic justice ("If it's wrong to poison communities, then it is wrong to profit from that poisoning"), and (3) our social and moral responsibility as institutions for the greater good ("Investments in fossil fuels are a denial of climate science"). Relevant sub-frames are also identified.

Equally and perhaps more important has been the movement's role in distilling, translating, and reframing the recent science on climate change into language that is accessible to the wider public while at same time invoking the language of the financial markets to engage with institutional investors. It has done so by taking research originally 
undertaken by the Potsdam Institute and reconstructing it using language that "names, interprets and dramatizes" it (Finnemore and Sikkink 1998, 896) and, in the process, constructing new cognitive frames. The Potsdam Institute had conceptualized the impact and consequences of climate change in terms of a "global carbon budget" (McGlade and Elkins 2015) that the world must not exceed if dangerous climate change is to be avoided. This report was reframed by financial think tank Carbon Tracker, which, in its report "Unburnable Carbon: Are the World's Financial Markets Carrying a Carbon Bubble?" (2014), argued that a substantial majority of usable fossil fuel would cease to be a valuable resource, becoming "stranded assets" whose shares would plummet in value.

While Carbon Tracker has been rightly credited with "chang[ing] the financial language of climate change" with its framing of "carbon bubbles" and "stranded assets" (Willis 2014), it was 350.org that succeeded in popularizing that message in such a way as to gain widespread media attention and to open a window through which to influence "hearts and minds." 350.org's particular talent was for a reframing technique involving a simple and graphic message and a "short causal story" (Stone 1998): there is a carbon budget, and exceeding it will have catastrophic consequences; therefore, we need to go "fossil free." Such a story provided a new master frame capable of being readily communicated to the broader public and shared with other network members while at the same time being couched in language likely to engage investors. As Carbon Tracker founder Mark Campanole put it, "Even though we had never advocated divestment, [350.org] framed the issue perfectly for NGOs, civil society groups and student movements around the world, and made financial institutions have to start to think about the issue" (Quoted in ESG Magazine 2015, 35). 
However, while astute naming, shaming and framing goes a considerable way towards explaining the early success of the divestment movement, the movement's future progress may be seriously constrained by the counter-movement that the fossil fuel industry and its allies are currently mounting against it.

\section{The Fossil Fuel Industry Countermovement}

Previous countermovements, orchestrated by powerful industry lobbies and their allies, have often achieved considerable success. In the US, McGarity, for example, has documented the considerable influence of "coordinated, well-funded, ideologically-driven campaigns conducted by the business community, small coteries of conservative funders and various foundations and institutions that they created" (McGarity quoted in Mintz 2014, 2). He also provides evidence that such coalitions have repeatedly outgunned their adversaries and have exercised a powerful influence on political outcomes and public opinion (McGarity 2014; see also Kim, Urpelainen and Yang 2015).

The present countermovement, like the divestment movement itself, relies heavily on effective framing. Climate change, as Hytten (2013) documents, is variously constructed by the countermovement as a conspiracy, a hoax, an unsupported theory, as not caused by humans, as real but not a serious problem, as existing but having largely benign consequences, or as something that can be effectively resolved through technology.

This countermovement is well placed to ensure that this framing is widely disseminated and effectively targeted. Not only does it have considerable influence 
over politicians by virtue of its substantial political contributions and through other means, but in some countries it also has influence, and sometimes control, over substantial sections of the media. In Australia, where Rupert Murdoch's News Corp Australia titles account for almost $60 \%$ of sales of all daily newspapers (and a slice of TV) that publisher's concerted opposition to any action on climate change (and its attacks on climate change science and scientists [Hamilton 2007]) have dovetailed neatly with the industry's own framing and served to further entrench its power. The industry has also turned to social media to match its adversaries' tactics, using Twitter, for example, under the guise of "Divestment Facts" (a project of the Independent Petroleum Association of America) to mirror the movement's own approach and to counter digital campaigning.

The industry has been particularly adept at placing its own carefully constructed stories and messages where they are most likely to shape public opinion. In doing so, it is no stranger to the dark arts of persuasion and "dirty tricks" campaigns (Mulvey and Shulman 2015; Oreskes and Conway 2010; McRight and Dunlap 2000). It has invested large sums of money to fund spurious NGOs and think tanks to cast doubt on the science of climate change, to discredit those who advocate for action, and to lobby politicians (Brulle 2014). Companies such as Exxon have been particularly effective merchants of doubt, disseminating disinformation with a campaign modeled on that which served the tobacco industry well for some decades (Goldenberg 2015; USC 2007).

The industry also engages in what the literature describes as "direct-action subversion" (Aronczyk and Auld 2014) in which the countermovement attacks those enterprises that have acquiesced to the movement's demands either directly or through its allies. For example, when the Australian National University became the first such 
Australian institution to divest, it was publicly attacked not just by the fossil fuel industry but by the Prime Minister, the Treasurer, and Australia's leading financial newspaper.

This battle for hearts and minds remains at the core of climate change policy and is currently playing out in what McAdam (referring to past social movements and their adversaries) describes as "an ongoing process of tactical interaction in which insurgents and opponents seek . . to offset the moves of the other" $(1983,736) .{ }^{8}$ Where the protagonists are relatively sophisticated in their responses, the contest between them has been likened to a game of chess (ibid. 1983). Whatever move the first player makes, the second will seek to counter it and, in so doing, may also seek to gain some longer-term strategic advantage. This process is repeated through multiple iterations. For example, many of the counterframes mirror those of the movement itself. Just as the movement appeals to morality, so too does the countermovement: if the people are denied access to fossil fueldriven electricity, then the poor will suffer most. Overcoming energy poverty by extending the fossil fuel-powered electricity grid in developing countries is the prescribed solution and is presented as a moral imperative. ${ }^{9}$

Whether or to what extent the divestment movement must continue to innovate, staying at least one step ahead of the countermovement, to maintain its upward trajectory remains to be seen. Experienced campaigners within the movement suggest that this may not be necessary:

As a movement, we aim to generate social energy, to support communities to fight locally. The industry can't match that directly because they can't generate a movement. Money doesn't buy movements although it may buy politicians. But they can't match our energy on the ground, you can't do that with a PR 
strategy. So we don't consider staying ahead, because we are playing a

different game." (350.org campaign strategist, USA).

While this may be true, evidence from the social movement literature suggests that staying ahead of the countermovement is also an important success factor ${ }^{10}$. While it is too soon to know how well the movement will adapt, the signs are that it is continuing to devise protest techniques and tactical innovations that offset its instrumental and institutional powerlessness, and that it is indeed staying some way ahead of its adversary. For example, while the primary form of disruption continues to be mediated through institutional investors, the movement also engages in multiple direct forms of disruption (King 2011), including its "Breakfree2016" campaign, billed as "the largest global moment of civil disobedience in the history of the environmental movement" (Ecowatch 2016a.), which involved direct actions across six continents and targeted "the world's most dangerous fossil fuel projects" (Ecowatch 2016b.).

However, while naming, blaming, and shaming as well as nimble and innovative tactics may go a considerable way toward advancing the movement's cause, how the contest ultimately plays out is also likely to be shaped by the relative power (and types of power) that the protagonists can marshal to advance their divergent goals.

\section{IV: Discussion: Divestment and the Nature of Power}

Traditionally, power in international relations has been viewed in instrumental terms as involving "the ability to make someone do something they would not do otherwise" (Dahl

1957, 203). Later writers have explored the structural and discursive dimension of power, 
emphasizing its socioeconomic and ideational institutions and structures (Fuchs and Lederer 2007). For present purposes, this article focuses on the power of business and civil society, in contrast to the more conventional state-centric approach taken by much of the literature.

While contemporary theorists see instrumental power as being only one dimension of power among many, it is nevertheless important and a helpful starting place for any exploration of the relative power of the divestment movement and the fossil fuel industry. Instrumental power in this context is most apparent in states rich in fossil fuel resources. In Australia, for example, one former political insider in the conservative party (the incongruously named Liberal Party) has documented how the coal mining industry and its allies successfully derailed climate change initiatives and how a self-styled "greenhouse mafia" successfully stymied discussion, let alone action, on climate change mitigation. He also documents how this group had access to cabinet papers, had a contentious cabinet decision reversed, and had its own representatives embedded in Australia's climate change delegations (Pearse 2007, 2010). Others have also described the close relationship between the coal mining industry and state and federal governments in Australia as well as the industry's overwhelming influence on political decision making (Baer 2016).

The American experience is not dissimilar, with lobbying, the provision of finance to political parties, and political capture being common themes (Carpenter 2001, 314-315). For example, in the US it is estimated that between 2010 and 2015 the oil and gas industry spent in excess of \$140 million per year on lobbying (OpenSecrets.org 2015). The influence of industry associations and of individual companies such as Exxon has been amplified by one of the most naked demonstrations of instrumental power, the political interventions of the Koch brothers and others, who have used their massive wealth to threaten any 
Republican Senator or member of Congress unwise enough to accept the science of climate change, let alone the dominance of fossil fuels, with removal from office (Mayer 2016).

Nevertheless, in the case of coal, at least in countries that are no longer major users or exporters of that resource, the industry's influence may be in decline. ${ }^{11}$ In the United States, energy demand has plateaued, unconventional gas and oil continue to grow at the expense of coal, renewable energy is becoming increasingly competitive, and, at least under the Obama administration, the proposed clean power plan (itself evidence that the influence of coal is far from hegemonic) threatened to impose further costs on the industry. Conventional gas, however, at least for the present, appears much less vulnerable since it can present itself as a "cleaner, greener" fuel than oil or coal (Macdonald-Smith and Sprague 2016) and as a necessary and desirable "transition fuel." Oil too remains a mainstay of the economy and has experienced less opprobrium than coal, although the campaign against the proposed Keystone XL tar sands pipeline suggests that it will come under more pressure in the future.

Structural analyses of power also emphasize the influence of business, focusing on its pivotal position in the economy and, in particular, on the extent to which governments are dependent on business activity to maintain the health of the economy and, through this, to improve their re-election chances. (Lindblom 1977). The result is to give business considerable power to shape the political agenda within the spheres of economic and industrial policy. In particular, the threat to withdraw capital, or reinvest it elsewhere, must be taken seriously by government, given that, by definition, in a capitalist system businesses make the final decisions about how capital is allocated (Farrell 2016). 
This approach resonates with the concept of a "second dimension of power" (Bachrach and Baratz 1970), which emphasizes the study of non-decision making and the creation of nonissues, or what others have termed the "non-problematisation" of particular issues, including climate change. (Freudenburg 2000). On this view, the structural power of industry can "predetermine behavioral options," and the "dependence of political elites on private sector profitability [can shape] political agendas and policy options" (Fuchs 2005, 775). Such a perspective is particularly useful in highlighting why some issues are never placed on the policy agenda.

However, precisely because structural power often involves "nondecisions," it is difficult to demonstrate and document. Nevertheless, Pearse's insider's account of the influence of the coal industry on decision making (and non-decision making) within the Liberal government in Australia largely overcomes this problem and provides a wealth of evidence that, at least in the case of the Australian coal industry, instrumental and structural power frequently operated in tandem to ensure that the centrality of coal to the Australian energy system was never challenged and that the issue of climate change never gained traction (Pearse 2007, see also Baer 2016). However, the extent to which corporations in general, or the fossil fuel industry in particular, have structural power may vary across states, industries, and contexts (Culpepper, 2016). For example, coal, unlike oil and gas, appears to be in structural decline (Caldecott et al. 2016; Citibank 2015), its plight epitomized by the Chapter 11 bankruptcy filing of Peabody, the world's largest private coal company (Miller and Jarzemsky 2016).

Nevertheless, in Australia the entrenched power of the industry described above has ensured not only that business uncertainty has largely stymied the growth of renewable 
energy but also that the coal industry continues to be heavily subsidized. A 2017 manifestation of this is the lending of AUS \$1 billion to the Indian mining conglomerate Adani to build the one of the largest coal mines on earth - a loan provided on extremely favorable terms and with remarkably little transparency. The loan is all the more surprising given that the Indian government has made clear its aim to fast track renewable energy and its intention to rely entirely on domestically produced coal to address energy needs in the transition period (Peetz and Murray 2017).

In contrast to the above, constructivists and others who emphasize discursive power recognize the extent to which power is a function of norms and ideas. How the dominant narrative is shaped, how an issue comes to be represented symbolically, and (more specifically) what we have termed "naming, blaming, and shaming" will be crucial in shaping perceptions and preferences and through this, policy outcomes. Shaming is viewed as "a mechanism through which movements promote new, often more universalistic moralities" (Seidman 2016, 352). And norms, in particular, are seen as crucial in influencing identity, interests, and behavior. As such: "material power matters but within a framework of normative expectations" (Reich 2003, 7).

Such an approach is consistent with Lukes' analysis of the "third face of power," defined as power that "stresses the force of social arrangements, which have already selected and excluded specific topics, worldviews, participants and modes of speaking before agents enter the picture" (Holzscheiter 2005, 731) — and, indeed, before agendas are set. This perspective recognizes that power can shape events even in circumstances in which there are no observable conflicts of interest in shaping perceptions and identities and thereby manufacturing consent (Fuchs 2005, 779). As Lukes puts it, "Is_it not the supreme exercise 
of power to get another or others to have the desires you want them to have-that is, to secure their compliance by controlling their thoughts and desires?” (Lukes 1974, 23).

Understanding the instrumental, structural, and discursive dimensions of power can provide considerable insights into how the contest between the divestment movement and the fossil fuel industry might play out. As will be apparent, the industry has substantial instrumental and structural power, particularly in states (such as Australia) whose economies rely heavily on the extraction of fossil fuels. Moreover, these types of power are increasing as the state comes to rely more and more on business for resources and inputs (Fuchs 2005, 782), enabling the latter to shape the behavior of political elites directly. In contrast, the divestment movement has very little instrumental power and even less structural power, and a contest fought on either terrain would be extremely one sided and would have an entirely predictable outcome.

As if this were not enough, the industry also has considerable discursive power and, as documented earlier, has set about manufacturing consent, much as the tobacco industry did before it. Not least, it has become adept at defining political problems (and nonproblems) in such a way as to complement its own interests. However, while the fossil fuel industry and its allies have succeeded in casting doubt on the science of climate change, in denigrating scientists, and in maintaining a degree of confusion and uncertainty in the minds of considerable sectors of the public as to the reality or severity of climate change (McCright and Dunlap (2003), they have not, ultimately, managed to keep the issue off the public policy agenda. In short, they failed to ensure that climate change remained a nonproblem. However, their multiple disinformation campaigns, often in tandem with those of conservative think tanks and others, have served to reduce public pressure for a transition 
to a low carbon economy and have delayed meaningful government action (Oreskes and Conway 2010, McCright and Dunlap 2003).

Yet "power as discourse" is a two-edged sword. For while discourse may serve as an important mechanism through which the conventionally powerful can embed and maintain their power, it is also essential to resistance and, indeed, may be harnessed by those bereft of instrumental and structural power as a starting point for an opposing strategy. This is well recognized by the divestment movement and it is precisely for this reason that it has chosen to challenge the industry in the one sphere in which the disparity of power between the two sides is perhaps bridgeable. As McKibben puts it, "We have to challenge them in a different currency. You can't fight a multi-billion-dollar corporation on their own terms."

That currency involves the exercise of discursive power in general and symbolic power in particular. The latter is something that NGOs have in plentiful supply, and indeed, as others have noted, "the term NGO, despite all its ambiguities, is loaded with symbolic power" (Bostrom and Hallstrom 2010, 26). The movement also has considerable cultural capital: Surveys consistently show that NGOs, including 350.org and its allies, are trusted more than not only corporations but also governments, churches, or the media (Bostrom and Hallstrom 2010; Jordan and van Tujil 2006), and this is clearly the sphere in which the movement is strongest. For these reasons, it is well-placed to shape norms and ideas and to challenge the "appropriateness" of a fossil fuel-based economy and of the need to go "fossil free," but less well-placed to challenge the industry's instrumental or structural power. Such a symbolic and normative focus may indeed offer "a unique opportunity to challenge institutions that are both powerful and 
highly resistant to change" (Raymond et al. 2014, 208). As we have seen, at least up to this point in the movement's development, its impact has been considerable and appears to be growing quickly. However, whether the movement's discursive power will be sufficient to trump the combined instrumental, structural, and discursive power of the fossil fuel industry remains to be seen.

Finally, another lens through which to understand the role and impact of the divestment movement is that of governance, defined here as authoritative societal steering (Andonova, Betsill, and Bulkeley 2009). In particular, the relevant question here is where the divestment movement should be located within the broader framework of "non-state climate governance"' (see Review Essay, Part 3, this Issue), given its interactions with and impact on a range of other climate actors.

As has been emphasized, the role of the divestment movement is primarily that of a moral entrepreneur concerned with promoting a new norm: the need to go "fossil free." The importance of this form of governance in shaping climate outcomes has already been elaborated in the Review Essay. Norms are not only pervasive but a fundamental underpinning to the functioning of individuals, organizations, and societies. They represent the glue that both connects potential allies and makes weak ties stronger as well as the battleground on which contests for legitimacy are fought. And it is precisely because the divestment movement is concerned with changing norms that its focus is on stigmatizing the fossil fuel industry and challenging the desirability of a fossil fuel-based economy. The importance of engaging in such a moral crusade, driven by norms and social understandings of acceptable behavior rather than pragmatic considerations, has been largely missed by students of nonstate environmental governance. Indeed, it may be that the 
preoccupation of existing studies with certification and standard setting has blinded writers to the extent to which outcomes in global environmental governance in general, and climate change governance in particular, are shaped not just by rules but also by norms, and that the latter, too, "represent some form of governance" (Kratochwil 2000, 53). Beyond this, however, it is also important to explore the form of governance in which the divestment movement is engaged and how this shapes its strategies and their outcomes.

Three models of governance are identifiable in the literature: markets, hierarchies such as the bureaucratic state, and networks (although others are also plausible) (Kooiman 2013). The divestment movement's campaigns clearly fall within the last category, involving purposive social steering through a multiplicity of agents who are bound together by a common discourse, who engage in activities that coalesce around "shared principled ideas," and who act in a coordinated fashion (Keck and Sikkink 1998, 2; Castells 2012). For example, in the US, the movement has worked closely with likeminded organizations and through vehicles such as the Fossil Fuel Divestment Student Network, while 350.org Australia is an influential member (along with its close allies) of the Climate Action Network Australia and leads the coalition of 13 NGOs orchestrating the Stop Adani campaign.

Those who work within the conceptual framework of network governance argue that the influence of nonstate actors such as NGOs, multinational corporations, and international financial institutions tends to be greatest when they work through policy and reform networks, which in turn engage in active "societal steering" and therefore governance. Scholarship on governance in general has shown the ways in which public and private governance has taken on networked forms and the benefits of such forms (Raustiala 2002, 
Castells 2000, Rhodes 1997), although there remains debate about whether such networks operate in the manner described in Rhodes' foundational texts (Rhodes 1997) or whether they take the form of "nodes" (Shearing and Wood 2003) or of "webs of influence" (Braithwaite and Drahos 2000).

However, what is most striking about the divestment movement, most notably in Australia, is the limited nature of its networks and its failure to reach beyond other activist organizations, who are "really the cooperative focus" (350A campaigner). In that country, when compared to a typical network combining "the voluntary energy and legitimacy of the civil society sector with the financial muscle and interest of the business and the enforcement and the rule-making power and coordination and capacity-building skills of states and international organizations" (Reinicke and Deng 2002), the movement's networks appear one dimensional. For the most part, they are concerned with coordinating particular campaigns with other activist groups and do little to "create a synergy between different competencies and sources of knowledge in order to deal with complex and interlinked problems" (Dedeurwaedere 2005, 2) as more developed networks do. Certainly there has been "a conscious effort to reach out to other organisations and groups" of late (350A campaign organizer), but for the most part even the movement's links with like-minded NGOs are limited, largely because its grassroots, bottom-up approach means that there is only a limited need for coordination. Certainly, its various national websites provide "how to" details for local groups, but with the exception of nationally or internationally orchestrated events, very limited organization is necessary. As the 350.org Australia website points out: "If you attend a 350 action for the first time, you might be surprised that there are probably no 350.org staff running the 
show."

This is not to suggest that the interrelation between the divestment movement and other climate change actors beyond like-minded climate NGOs is unimportant-quite the contrary. The point is that, in Australia in particular, few of these interrelations are a consequence of networking, but nevertheless complementarity, mutual reinforcement, or synergy may serve to amplify the movement's impact in particular circumstances. For example, even without significant networking, various international organizations (IOs), and key individuals within them, have endorsed the movement, thereby contributing to its legitimacy and effectiveness. This is no small matter. Sympathetic IOs can promote the embryonic norm of going "fossil free" among nation states and other entities; act as orchestrators who build capacity, facilitate collaboration, and provide support to other climate actors; and promote international standards. The movement has also benefitted from the fast-growing "sustainable finance" and "impact investment" arms of some banks and global consultancy firms. These entities, under the guise of "doing well by doing good," and in pursuit of niche markets, have disseminated the message of climate risk to institutional investors, many of whom are beyond the reach of the divestment movement. Again, while relationships with this group are arms length, they are nevertheless symbiotic. Consistent with the divestment movement's message (and in ways that are mutually reinforcing, but also in the absence of networking), some other influential financial actors (including the Governor of the Bank of England, Mark Carney) are also beginning to shift perceptions of what constitutes "risky business,"

None of this should be taken to imply that more extensive networking by the movement is unnecessary or would not be to its advantage. Indeed, the best way forward for 
the movement might well be to benefit from existing (non-networked) synergies and complementarities while also seeking to extend and deepen its networks. There is some evidence that the movement may be on the cusp of doing precisely that. 350.org Executive Director May Boeve, in particular, has called for the movement to actively engage in “transition alliances" (Boeve 2015). A subsequent and empirically based consultant's report makes a strong case for an approach to building grassroots power using powerful story telling (350.org's strong suit) in conjunction with harnessing the opportunities provided by an increasingly networked society. This, they argue, requires "directed-network campaigning" with an emphasis on "cross-movement network hubs" harnessing the agility of modern communications (Mogus and Liacas 2016).

This message appears to have been taken up with much greater enthusiasm in the United States than in Australia. In the latter, as one activist put it, "One of my chief frustrations is our inability to overcome the hurdle of engaging broad audiences." Similarly, according to one international consultant, "I don't see a commitment to intersectional organizing. Australia is ten to fifteen years behind North America." What still remains necessary, according to another Australian climate activist, is "inspired, determined advocates who work from 'down-up' or from 'across over to' so like-minded people will act on their existing values" (Australian Religious Response to Climate Change).

\section{V: Conclusion}

Top-down climate initiatives orchestrated through mechanisms of international cooperation and coordination and through international agreements can and should play 
crucial roles in shaping our climate future. However, bottom-up approaches are also important, not least in stimulating changes in beliefs and norms and, through this, in influencing behavioral change. Indeed, history suggests that international agreements are most likely to be pursued with sufficient determination as to make them effective if there is a groundswell of popular support. Accordingly, bottom-up norm development may be the foundation on which effective top-down action can be built.

Despite being barely five years old, the divestment movement, a quintessential example of moral entrepreneurship, is now at the forefront of civil society initiatives to raise public consciousness about the need for a "fossil-free" future. Realizing the opportunities that divestment provides for political engagement but lacking material resources, it has been adept at harnessing grassroots activists though multiple locally-driven campaigns and through innovative (and often disruptive) forms of activism, coordinated nationally and internationally. These initiatives have sought to name and shame the fossil fuel industry and to threaten its social license to operate. Crucially, the movement has recognized the importance of cognitive framing and symbolic politics in gaining media interest, in persuading the public of the importance and legitimacy of its claims, and in translating climate change science into language that is readily understood by target audiences. Finally, recognizing the embedded institutional and instrumental power of its adversary and its own weakness in these areas, it has managed to shift the contest, at least in part, onto terrain in which it might hold a comparative advantage. To date it has had some significant successes, but the growing strength and sophistication of the fossil fuel industry countermovement, whose efforts at reframing and multiple disinformation campaigns have gained considerable traction, 
threatens its future progress.

Overall, the messy reality is that climate policy and governance is not only a topdown process involving states and international agreements but also a bottom-up, polycentric process involving civil society and the corporate sector. And it is not only an instrumental process of coercing changes in behavior and in the exercise of material power but also an expressive and symbolic one of nurturing new norms and institutionalizing a new set of moral principles. Whether moral entrepreneurs such as the divestment movement, in tandem with a cluster of other climate agents, will succeed in precipitating a "norm cascade" and whether this, in conjunction with the higher level of international commitment evidenced by the Paris Agreement, will be enough to avert the cataclysm of dangerous climate change remains an open question ${ }^{12}$.

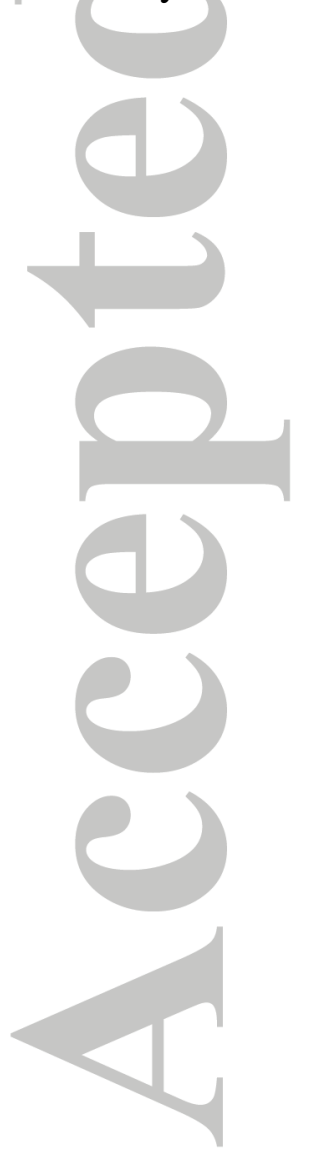




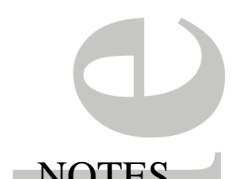

NOTES

${ }^{1}$ I am grateful for the excellent research assistance of Lucy Caldwell and David Rowe and for the comments of Julie Ayling, Christian Downie, Darren Sinclair, and two anonymous reviewers. Responsibility for any errors is, of course, my own.

${ }^{2}$ For present purposes, divestment is viewed as a tactic (indeed the principal tactic) supporting a strategy for achieving climate change mitigation by promoting a new social norm.

${ }^{3}$ Emphasis in the original. Fossil fuel companies, for the divestment movement, include those whose primary activity is the extraction of fossil fuels, but this has gradually extended to include electrical utilities that use fossil fuels (particularly coal) to generate electricity.

${ }^{4} \mathrm{I}$ am indebted to an anonymous reviewer for this point.

${ }_{6}^{5} \mathrm{I}$ am indebted to an anonymous reviewer for this point.

${ }^{6}$ Nevertheless, the movement does anticipate that some fossil fuel stocks will ultimately become stranded assets, although it has no illusions about shifting share prices of individual stocks in the short term [I removed "or" from the phrase "share prices of individual stocks or in the short term"] (see Gunningham 2017 this issue). Its more pragmatic arm, DivestInvest, highlights the importance of reinvesting in sustainable enterprises. As such, this article does not subscribe to the view that there is necessarily a dichotomy between expressive and instrumental politics, but it does argue that the former is the central concern of 350.org and its allies.

7 Sometimes referred to as "franchise activism," a term that refers to forms of activism carried out by autonomous groups in different localities under the same name.

${ }^{8}$ Emphasis in original.

${ }^{9}$ This framing is attributed to major coal producer Peabody. See in particular its Advanced Energy for Life website'The truth behind Peabody campaign to rebrand coal as a poverty cure Guardian ref On a conventional analysis 'climate change will wipe out crucial gains in development and poverty reduction in the global South, and will trigger food shortages, conflict, epidemic disease, and mass displacement. [I'm not sure what's happening at the end of this sentence- - is this note incomplete? See if you can revisit this.]

${ }^{10}$ Empirical studies suggest that innovative tactics are more successful than simply repeating past ones. See, for example, McAdam (1983). See also McCright and Dunlap $(2000,517)$, who argue that the difficulty advocates have in keeping climate change on the agenda is due more to the success of the countermovement than a function of waning media attention.

${ }^{11}$ However, this is far from being the case in the developing world, where India, for example, plans the substantial expansion of both solar power and of domestic coal production to fuel its future growth (Kulshrestha, 2016). 
12. A normative complement to the present article, provisionally entitled "Mobilising Civil Society: Can the Climate Movement Achieve Transformational Social Change?” is planned for publication in 2018 .

Neil Gunningham is a lawyer and social scientist working principally in the areas of environmental regulation and governance. He is a Professor in the School of Regulation and Global Governance (RegNet) at the Australian National University. His books include Smart Regulation: Designing Environmental Polic (with Grabosky) and Shades of Green: Business, Regulation and Environment (with Kagan and Thornton).

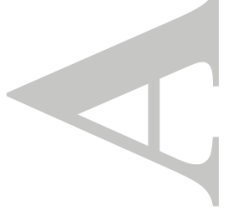

\section{References}

350.org. 2014. Fossil Free: A Campus Guide to Fossil Fuel Divestment. http://gofossilfree.org/wpcontent/uploads/2014/05/350_FossilFreeBooklet_LO4.pdf.

Anderson, Gary L. and Kathryn G. Herr (eds.). 2007. Encyclopedia of Activism and Social Justice. Thousand Oaks, CA: Sage Publications.

Arabella Advisors. 2015. Measuring the Growth of the Global Fossil Fuel Divestment and Clean Energy Investment Movement. http://www.arabellaadvisors.com/wpcontent/uploads/2015/09/Measuring-the-Growth-of-the-Divestment-Movement.pdf.

Arabella Advisors. 2016. The Global Fossil Fuel Divestment and Clean Energy Investment Movement. https://www.arabellaadvisors.com/wpcontent/uploads/2016/12/Global_Divestment_Report_2016.pdf.

Aronczyk, M. and Auld, G. [We prefer full names over abbreviations on the references page. If it isn't too much trouble, please replace initials with full names.]. 2013. Tar, Ethics, and Other Tactical Repertoires: The Coevolution of Movements for and against the Tar Sands. Working Paper.

Baer, Hans. 2016 "The Nexus of the Coal Industry and the State in Australia: Historical Dimensions and Contemporary Challenges." Energy Policy, in press.

Bachrach, P. and Baratz, M. 1962. "Two Faces of Power," American Political Science Review 56: 947-52.

Baron, David P. 2001. "Private Politics, Corporate Social Responsibility, and Integrated Strategy," Journal of Economics \& Management Strategy 10 (1): 7-45. 
Beinecke, Frances. 2015. "How to Unleash Climate Action: Values, Politics and the Inevitability of the Clean Energy Future," Social Research 82 (3): 713-718.

Boeve, May. 2015. Join the Fossil Fuel Divestment Movement., 2 June 2015. https://disrupt-andinnovate.org/join-the-fossil-fuel-divestment-movement/.

Black, Julia. 2008. “Constructing and Contesting Legitimacy and Accountability in Polycentric Regulatory Regimes," Regulation and Governance 2: 137-164.

Braithwaite, John, and Peter Drahos. 2000. Global Business Regulation. Cambridge: Cambridge University Press.

King, Brayden G. 2011. "The Tactical Disruptiveness of Movements: Sources of Market and Mediated Disruption in Corporate Boycotts," Social Problems 48: 491-517.

Brulle, Robert J. 2014. "Institutionalizing Delay: Foundation Funding and the Creation of U.S. Climate Change Counter-Movement Organizations," Climatic Change 22: 681-694.

Bulkeley, Harriet et al. 2014. "Transnational Climate Change Governance”. New York: Cambridge University Press 15 (4): 136-138.

Caldecott, Ben et al. 2016 "Stranded Assets and Thermal Coal: An analysis of environment-related risk exposure". Smith School of Enterprise and Engagement.

http://www.smithschool.ox.ac.uk/research-programmes/stranded-assets/satc.pdf.

Carbon Tracker Initiative and Grantham Research Institute for Climate change and the Environment. 2014. Unburnable Carbon: Wasted Capital and Stranded Assets. http://carbontracker.live.kiln.digital/Unburnable-Carbon-2-Web-Version.pdf.

Carbon Tracker. 2014. Unburnable Carbon - are the world's financial markets carrying a carbon bubble? www.carbontracker.org/wp-content/uploads/2014/09/Unburnable-Carbon-Fullrev2-1.pdf.

Carpenter, Chad. 2001. "Businesses, Green Groups and the Media: The Role of Non-Governmental Organizations in the Climate Change Debate." International Affairs 77 (2): 313-28.

Carrington, Damian. 2013. "Campaign Against Fossil Fuels Growing, Says Study,” The Guardian. https://www.theguardian.com/environment/2013/oct/08/campaign-against-fossil-fuelgrowing.

Castells, Manuel. 2012. Networks of Outrage and Hope: Social Movements in the Internet Age. Cambridge, UK: Polity Press.

Citibank. 2015. Manoeuvring an Uneven Recovery-Annual Outlook. https://www.citibank.co.id/global_docs/monthly_outlook/2015annual_outlook_cg.pdf.

d'Anjou, Leo. 1996. Social Movements and Cultural Change: The First Abolition Campaign Revisited. Hawthorne, NY: Aldine de Gruyter.

Dahl, Robert Alan. 1957. "The Concept of Power," Systems Research and Behavioural Science 2 (3): 201-215.

Dedeurwaedere, Tom. 2005. "The Contribution of Network Governance to Sustainable Development," École Polytechnique. http://www.iddri.org/Evenements/Seminairesreguliers/s13_dedeurwaerdere.pdf. 
Dellas, Eleni, Philipp Pattberg, and Michele Betsill. 2011. "Agency in Earth System Governance: Refining a Research Agenda," International Environmental Agreements: Politics, Law and Economics 11 (1): 85-98.

Divest-Invest Philanthropy. 2015. Doing Good: Performing Better. http://divestinvest.org/philanthropy/wp-content/uploads/sites/3/2016/01/12.22_DivestInvest-Brief_web2.pdf.

Edelman, M. 1971. Politics as Symbolic Action: Mass Arousal and Quiescence. New York: Academic Press.

Eaton, Heather. 2011. “An Ecological Imaginary.” In Ecological Awareness: Exploring Religion, Ethics and Aesthetics, vol. 3, edited by Sigurd Bergmann and Heather Eaton. Munster, Germany: LIT Verlag.

Ecowatch. 2016. Largest Civil Disobedience in History of the Environmental Movement Begins Today. http://www.ecowatch.com/largest-civil-disobedience-in-history-of-theenvironmental-movement-be-1891128328.html.

Ecowatch. 2016. Tens of Thousands Take Part in Global Actions Targeting World's Most Dangerous Fossil Fuel Projects. http://www.ecowatch.com/tens-of-thousands-takepart-in-global-actions-targeting-worlds-most-da-1891130927.html.

ESG Magazine. 2015. “A New Breed of Financial NGO.” In COP21: Green Deal or Green Wash?. http://www.sustainablefinance.ch/upload/cms/user/02_2015_ESG_Magazine.pdf.

Farrell, H. 2016. "Behind Structural Power Lies Structuring Power," Duck of Minerva (blog), February 3, 2016. http://duckofminerva.com/2016/02/behind-structural-power-liesstructuring-power.html

Finnemore, Martha, and Kathryn Sikkink. 1998. "International Norm Dynamics and Political Change," International Organization 52 (4): 887-917.

Freudenburg, William R. 2000. "Social Constructions and Social Constrictions: Toward Analyzing the Social Construction of 'The Naturalized' as well as 'The Natural.'” In Environment and Global Modernity, edited by Gert Spaargaren, Arthur P. J.Mol, and Frederick H. Buttel, 103-119. London: Sage.

Fuchs, Doris, and Marcus Lederer. "The Power of Business," Business and Politics 9 (1): 1-17.

Gamson, William A. and David S. Meyer. 1996. "Framing Political Opportunity." In Comparative Perspectives on Social Movements: Political Opportunities, Mobilizing Structures, and Cultural Framings, edited by Doug McAdam, John D. McCarthy, and Mayer N. Zald. New York: Cambridge University Press.

GoFossilFree.org. 2015. Global Divestment Day. http://gofossilfree.org/creative-action-ideas/.

Goldenberg, Suzanne. 2015. Paris Climate Summit: The Climate Circus Comes to Town. The Guardian. https://www.theguardian.com/environment/2015/nov/26/paris-climate-changeconference-circus-comes-to-town.

Gunningham, Neil. 2017. "Review Essay: Divestment, Social Movements and Climate Governance," Law and Policy 39 (4). 
Gusfield, Joseph R. 1963. Symbolic Crusade: Status Politics and the American Temperance Movement. Urbana, IL: University of Illinois Press.

Hallström, Kristina Tamm, and Magnus Boström. 2010. Transnational Multi-Stakeholder Standardization: Organizing Fragile Non-state Authority. Cheltenham, UK: Edward Elgar Publishing.

Hamilton, Clive. 2007. Scorcher: The Dirty Politics of Climate Change. Melbourne: Black Inc. Agenda.

Hansen, James, Mahiko Sato, and Pushker Kharecha et al. [Please list all authors' names here, rather than using "et al."] 2008. "Target atmospheric CO2: Where Should Humanity Aim?" The Open Atmospheric Science Journal 2 (1): 217-31.

Holzscheiter, Anna. 2005. "Discourse as Capability: Non-State Actors' Capital in Global Governance”, Millenium: Journal of International Studies 33 (3) 723-746

Hytten, Karen. 2013. The Social Construction of Climate Change: Deconstructing the Climate Change Debate in Australia. School of Environment, Griffith University. https://experts.griffith.edu.au/publication/n97ac3f084b3aa836abd2a326e9204ba8.

Jarvis, Brooke. 2013. Can a Divestment Campaign Move the Fossil Fuel Industry? Yale 360. http://e360.yale.edu/feature/can_a_divestment_campaign_move_the_fossil_fuel_industry/26 291.

Jordan, Lisa and Peter van Tujil (eds.). 2006. NGO Accountability: Politics, Principles and Innovations. London: Earthscan.

Keck, Margaret E., and Kathryn Sikkink. 1998. Activists Beyond Borders: Advocacy Networks in International Politics. Ithaca, NY: Cornell University Press.

Keck, Margaret E., and Kathryn Sikkink. 1999. "Transnational Advocacy Networks in International and Regional Politics,” International Social Science Journal 51 (1): 89.

Kim, Sung Eun, Johannes Urpelainen, and Joonseok Yang. 2015. "Electric Utilities and American Climate Policy: Lobbying by Expected Winners and Losers," Journal of Public Policy 36 (2): 251-75.

King, Brayden G. 2011. "The Tactical Disruptiveness of Social Movements: Sources of Market and Mediated Disruption in Corporate Boycotts," Social Problems 58 (4): 491-517.

Kollman, Ken. 1998. Outside Lobbying: Public Opinion and Interest Group Strategies. Princeton, N.J: Princeton University Press.

Kooiman, Jan. 2003. Governing as Governance. London: SAGE.

Koopmans, Ruud, 2004. "Movements and Media: Selection Processes and Evolutionary Dynamics in the Public Sphere," Theory and Society 33 (3/4): 367-91.

Kulshrestha, Ashish. 2016. "India to Touch 15 GW Solar Power Production," The Economic Times

September 1, 2016. http://economictimes.indiatimes.com/industry/energy/power/india-totouch-15-gw-solar-power-production-by-march-2017/articleshow/53966358.cms.

Linnenluecke, Martina K., Cristyn Meath, Saphira Rekker, Baljit Sidhu, and Tom Smith. "Divestment from Fossil Fuel Companies: Confluence between Policy and Strategic 
Viewpoints," Australian Journal of Management 40 (3). Available at SSRN:

https://ssrn.com/abstract=2661574

Lindblom, Charles E. 1977. Politics and Markets: The World's Political-Economic Systems. New York: Basic

Lukes, Steven. 1974. Power: A Radical View. Hampshire: Palgrave Macmillan.

Macdonald-Smith, Angela, and Julie-Anne Sprague. 2016. Gas Industry Claims That It's Cleaner, Greener than Coal. Australasian Business Intelligence. https://www.highbeam.com/doc/1G1-449136596.html.

MacLeod, Michael, and Jacob Park. 2011. "Financial Activism and Global Climate Change: The Rise of Investor-Driven Governance Networks," Global Environmental Politics 11 (2): 5474.

Mayer, Jane. 2016. Dark Money: The Hidden History of the Billionaires Behind the Rise of the Radical Right. New York City, NY: Doublebay.

McAdam, Doug, John D. McCarthy, and Mayer N. Zald (eds.). 1996. Comparative Perspectives on Social Movements: Political Opportunities, Mobilizing Structures, and Cultural Framings. New York: Cambridge University Press.

McAdam, Doug, Sidney G. Tarrow, and Charles Tilly. 2001. Dynamics of Contention. New York: Cambridge University Press.

McAdam, Doug. 1983. "Tactical Innovation and the Pace of Insurgency," American Sociological Review 48 (6): 735-54.

McCright, Aaron M., and Riley E. Dunlap. 2000. "Challenging Global Warming as a Social Problem: An Analysis of the Conservative Movement's Counter-Claims," Social Problems 47 (4): 499-522.

McCright, Aaron M., and Riley E. Dunlap. 2003. Defeating Kyoto: The Conservative Movement's Impact on U.S. Climate Change Policy. vol. 50. Berkeley: University of California Press.

McCright, Aaron M., and Riley E. Dunlap. 2011. Organized Climate Change Denial. Oxford University Press.

McGarity, Thomas O. 2014. "The Disruptive Politics of Climate Disruption," Nova Law Review 38 (3): 393.

McGlade, Christophe, and Paul Ekins. 2015. "The Geographical Distribution of Fossil Fuels Unused When Limiting Global Warming to $2{ }^{\circ} \mathrm{C}$," Nature 517 (7533): 187-90.

McKibben, Bill and Christian Parenti. 2013. Will 350.org Fossil Fuel Divestment Campaign Be Key Tactic in 2013 Battle over Climate Change?. Democracy Now. http://www.democracynow.org/2013/1/2/will_350org_fossil_fuel_divestment_campaign.

McKibben, Bill. 2012. Global Warming's Terrifying New Math. Rolling Stone.

http://www.rollingstone.com/politics/news/global-warmings-terrifying-new-math20120719. 
Miller, John W. and Matt Jarzemsky. 2016. "Peabody Energy Files for Chapter 11 Bankruptcy Protection," The Wall Street Journal April 14. http://www.wsj.com/articles/peabodyenergy-files-for-chapter-11-protection-from-creditors-1460533760.

Minichiello, Victor. 1995. In-Depth Interviewing: Principles, Techniques, Analysis. 2nd ed. Melbourne: Longman.

Mintz, Joel A. 2014. "Introduction: Climate Disruption and Governmental Action: Approaches, Obstacles, and Opportunities," Nova Law Review 38 (3): 1-6.

Mogus, Jason and Tom Liacas. 2016. Networked Change: How Progressive Campaigns Are Won in the $21^{\text {st }}$ Century. Netchange Consulting.

Mulvey, Kathy and Seth Shulman. 2015._The Climate Deception Dossiers. Cambridge MA: Union of Concerned Scientists. http://www.ucsusa.org/sites/default/files/attach/2015/07/TheClimate-Deception-Dossiers.pdf.

Open Secrets,. 2015. Oil and Gas. https://www.opensecrets.org/industries/indus.php?ind=E01 accessed 16 Nov 2016.

Oreskes, Naomi and Erik M. Conway. 2010. Merchants of Doubt: How a Handful of Scientists Obscured the Truth on Issues from Tobacco Smoke to Global Warming. New York: Bloomsbury Press.

Pearse, Guy. 2007. High \& Dry: John Howard, Climate Change and the Selling of Australia's Future. Camberwell, VIC: Viking/Penguin.

Pearse, Guy. 2010. "The Land of the Long Black Cloud,” The Monthly: Australian Politics, Society and Culture September 2010.

https://www.themonthly.com.au/issue/2010/september/1283393182/guy-pearse/land-longblack-cloud.

Peetz, David and Georgina Murray. 2017. "The Government is Swimming Against the Tide on Westpac's Adani Decision,” The Conversation May 3.

Pepper D Culpepper 2016. "Structural Power and Contemporary Politics," Duck of Minerva (blog), February 1, 2016. http://duckofminerva.com/2016/02/structural-power-and-contemporarypolitics.html.

Piven, Frances Fox, and Richard A. Cloward. 1979. Poor People's Movements: Why They Succeed, How They Fail. New York: Vintage Books.

Reich, Simon. 2003. Power, Institutions and Moral Entrepreneurs. ZEF Bonn. http://www.zef.de/uploads/tx_zefportal/Publications/zef_dp65.pdf

Raymond, Leigh, S. Laurel Weldon, Daniel Kelly, Ximena B. Arriaga, and Ann Marie Clark. 2014. "Making Change: Norm-Based Strategies for Institutional Change to Address Intractable Problems," Political Research Quarterly 67 (1): 197-211.

Reich, Simon. 2003. "Power, Institutions, and Moral Entrepreneurs," ZEF Discussion Papers on Development Policy, Paper 65, Bonn.

Reinicke, Wolfgang H., and Francis Deng. 2002. Critical Choices: The United Nations, Networks and the Future of Global Governance. Ottawa: IDRC. 
Richardson, David. 2014. Beyond Fossil Fuels: The Investment Case for Fossil Fuel

Divestment. Impax Asset Management. http://www.impaxam.com/media-

centre/white-papers/beyond-fossil-fuels-investment-case-fossil-fuel-divestment.

RiskyBusiness. 2014. A Climate Risk Assessment for The United States. http://riskybusiness.org/site/assets/uploads/2015/09/RiskyBusiness_Report_WEB_09_08_1 4.pdf.

Saunders, Amanda. 2014. "Anglo American Seeks Support to Keep the Faith with Fossil Fuels," Sydney Morning Herald September 22.

Seidman, Gay, W. 2015. "Divestment Dynamics: Mobilizing, Shaming and Changing the Rules," Social Research 82 (4).

Sikkink, Kathryn. 2005. "Patterns of Dynamic Multilevel Governance and the Insider-Outsider Coalition." In Transnational Protest and Global Activism, edited by Donatella Della Porta and Sidney G. Tarrow. Lanham, MD: Rowman \& Littlefield.

Stop Adani. 2017. Stopping Adani Coal is the Fight of Our Times. http://www.stopadani.com.

Stevens, Matthew. 2016. No charity for Green Law Breakers. Financial Review. http://www.afr.com/opinion/columnists/no-charity-for-green-law-breakers-20160504gom975\#ixzz48xoeGiZF.

Stone, Deborah A. 1989. "Causal Stories and the Formation of Policy Agendas," Political Science Quarterly 104 (2): 281-300.

Suchman, Mark C. 1995. "Managing Legitimacy: Strategic and Institutional Approaches," The Academy of Management Review 20 (3): 571-610.

Trillium Asset Management. 2014. Extracting Fossil Fuels from Your Portfolio: A Guide to Personal Divestment and Reinvestment. http://www.trilliuminvest.com/wpcontent/uploads/2013/10/ExtractingFossilFuels.pdf.

Union of Concerned Scientists. 2007. Smoke, mirrors \& hot air: How ExxonMobil Uses Big Tobacco's Tactics to Manufacture Uncertainty on Climate Science. http://www.ucsusa.org/sites/default/files/legacy/assets/documents/global_warming/exxon_re port.pdf.

Vaughn, Adam. 2014. "Fossil Fuel Divestment: A Brief History," The Guardian October 8. https://www.theguardian.com/environment/2014/oct/08/fossil-fuel-divestment-a-briefhistory

Yaziji, Michael, and Jonathan P. Doh. 2013. "The Role of Ideological Radicalism and Resource Homogeneity in Social Movement Organization Campaigns against Corporations," Organization Studies 34 (5-6): 755-80.

Zald, Mayer N., and John D. McCarthy. 1987. Social Movements in an Organizational Society: Collected Essays. New Brunswick, U.S.A: Transaction Books.

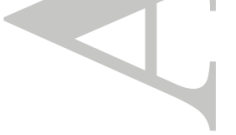

